\title{
The protective role of melatonin against the effect of caffeine on embryonic kidney
}

\author{
Kafeinin embriyonel böbrek gelișimine olan etkisine karşı melatoninin \\ koruyucu rolü
}

Seher YILMAZ1, Ayşe Yeşim GÖÇMEN², Arda Kaan ÜNER², Enes AKYÜZ4, Adem TOKPINAR ${ }^{1}$

\section{ABSTRACT}

Objective: Oxidative stress is one of the major causes of embryonal developmental disorders. In addition, melatonin reduces oxidative stress in the body and is known as a potential treatment for adverse effects of caffeine on fetal development. In this study, we aimed to investigate the teratogenic effect of caffeine on fetal kidney development and the protection of melatonin against the teratogenicity in terms of biochemical parameters.

Methods: $5-7$ months old Wistar-Albino rats $(n=24)$ weighing 180-220 g were divided into seven groups for control, caffeine, melatonin, and caffeine+melatonin (co-injection). Control group: Serum physiological (SF) as $1 \mathrm{~mL} / \mathrm{kg}$ intraperitoneal (i.p.), Sham group: 0.1 $\mathrm{ml}$ hanks as i.p., Low dose caffeine group: $30 \mathrm{mg} / \mathrm{kg}$ caffeine as gavage, Low dose caffeine+melatonin group: $30 \mathrm{mg} / \mathrm{kg}$ dose gavage with $10 \mathrm{mg} / \mathrm{kg}$ melatonin as i.p., High dose caffeine group: $60 \mathrm{mg} / \mathrm{kg}$ caffeine as gavage, High dose caffeine+melatonin group: $60 \mathrm{mg} / \mathrm{kg}$ dose gavage with $10 \mathrm{mg} / \mathrm{kg}$ melatonin as i.p., and Melatonin group: $10 \mathrm{mg} / \mathrm{kg}$ melatonin as i.p.

Results: Total antioxidant status (TAS) values were $0.49 \pm 0.02$ in the control group and $0.14 \pm 0.00$ in the high

\section{ÖZET}

Amaç: Oksidatif stres embriyonel gelișim bozukluklarının en büyük sebeplerinden biridir. Ayrıca, melatonin vücutta oksidatif stresi azaltması nedeniyle kafeinin fetal gelișime olan olumsuz etkilerine karșı potansiyel bir tedavi yöntemi olarak görülmektedir. $\mathrm{Bu}$ çalıșmada; kafeinin fetal böbrek gelișimine olan teratojenik etkisi ve melatonin maddesinin bu teratojeniteye karșı koruyuculuğunu biyokimyasal parametreler üzerinden incelemeyi hedeflenmiștir.

Yöntem: Çalıșmada, 180-220 g ağırlığında 24 adet 5-7 aylık Wistar-Albino ırkı ratlar; kontrol, kafein, melatonin ve hem kafein hem de melatonin enjekte edilmek üzere yedi gruba ayrılmıtır. Kontrol grubu: Serum fizyolojik (SF), (1ml/kg) intraperitoneal (i.p.) Sham grubu: $0.1 \mathrm{~mL}$ hanks i.p., Düşük doz kafein grubu: $30 \mathrm{mg} / \mathrm{kg}$ kafein gavaj olarak Düșük doz kafein+Melatonin grubu: $30 \mathrm{mg} / \mathrm{kg}$ dozda gavaj ile $10 \mathrm{mg} / \mathrm{kg}$ melatonin i.p., Yüksek doz kafein grubu: $60 \mathrm{mg} / \mathrm{kg}$ kafein gavaj, Yüksek doz kafein+Melatonin grubu: $60 \mathrm{mg} / \mathrm{kg}$ dozda gavaj ile $10 \mathrm{mg} / \mathrm{kg}$ melatonin i.p, Melatonin grubu: $10 \mathrm{mg} / \mathrm{kg}$ melatonin i.p. olarak verilmiștir.

Bulgular: Alınan böbrek dokularında biyokimyasal değerler incelendiğinde, total antioksidan kapasite

'Yozgat Bozok University, Faculty of Medicine, Department of Anatomy, Yozgat

${ }^{2}$ Yozgat Bozok University, Faculty of Medicine, Department of Biochemistry, Yozgat

${ }^{3}$ Yozgat Bozok University, Faculty of Medicine, Yozgat

${ }^{4}$ Yozgat Bozok University, Faculty of Medicine, Department of Biophysics, Yozgat

İletişim / Corresponding Author : Seher YILMAZ

Yozgat Bozok Üniversitesi Tip Fakültesi, Anatomi Anabilim Dalı, Yozgat - Türkiye

Tel : +905363446763 E-posta/E-mail : sehery38@hotmail.com

Geliş Tarihi/Received : 19.12.2019

Kabul Tarihi/Accepted : 05.01.2020

DOI ID : 10.5505/TurkHijyen.2020.77675

Yılmaz S, Göçmen AY, Üner AK, Akyüz E, Tokpınar A. The protective role of melatonin against the effect of caffeine on embryonic kidney.

Turk Hij Den Biyol Derg, 2020; 77(1): 51-58 
dose caffeine group. In addition, total oxidant status (TOS), oxidative stress index (OSI), glutathione (GSH), glutathione disulfide (GSSG), superoxide dismutase (SOD), thiobarbituric acid reactive substances (TBARS), calcium (Ca), vitamin D and GSH/GSSG levels were examined $(p<0.001)$.

Conclusion: Melatonin has shown that caffeine has an essential role in reducing teratogenic effects and also reducing oxidative stress. Therefore, melatonin is a potential treatment for oxidative stress and caffeine teratogenicity in embryonic development.

Key Words: Caffeine, rat, melatonin, kidney
(TAS) değeri kontrol grubunda $0,49 \pm 0,02$, yüksek doz kafein grubunda $0,14 \pm 0.00$ olduğu görülmüștür. Ayrıca total oksidan kapasite (TOS), oksidatif stres indeksi (OSI), glutatyon (GSH), glutatyon disülfit (GSSG), süperoksit dismutaz (SOD), tiyobarbitürik asit reaktif maddeler (TBARS), Kalsiyum (Ca), D vitamini ve GSH/ GSSG seviyeleri incelenmiștir $(p<0,001)$.

Sonuç: Melatoninin kafeinin teratojenik etkilerini ve oksidatif stresi azaltmada önemli bir role sahip olduğunu göstermiștir. Bu nedenle melatonin, embriyonel gelișimde oksidatif stres ve kafein teratojenitesi için potansiyel tedavi niteliği tașımaktadır.

Anahtar Kelimeler: Kafein, sıçan, melatonin, böbrek

\section{INTRODUCTION}

Oxidative stress is defined as the presence of active oxygen species above the available antioxidant buffering capacity. These products may damage proteins, lipids, and DNA that alter reactive oxygen species, the structure, and function of the organism. Tissue damage is caused by a series of enzymes that produce highly reactive intermediate compounds free radicals and non-enzyme-mediated biochemical reactions $(1,2)$.

Although oxidative stress is a feature of normal pregnancy, it affects the antioxidant capacity of the placenta, leading to the consumption and reduction of antioxidants. The high course of oxidative stress damages the lipids, proteins, and DNA in the placental tissue, causing an accelerated aging form. The premature aging of the placenta is associated with placental insufficiency, which prevents the organ and the fetus from addressing their needs, and as a result, the viability of the fetus is compromised. In addition, high doses of caffeine taken during pregnancy are known to cause oxidative stress (3).

Caffeine (1,3,7-trimethylxanthine) has been a common component of human nutrition for thousands of years, given its behavior and stimulating

effects (4). Caffeine is the most commonly used psychostimulant in Western countries $(5,6)$. Caffeine is rapidly absorbed from the gastrointestinal tract and the highest caffeine concentration is reached 30-60 minutes after consumption $(6,7)$. In addition to the organism, factors such as caffeine consumption time, sex, physiological status, and temperature also affect the pharmacokinetics of caffeine. In animal studies, teratogenic and embryotoxic effects of high caffeine doses have been determined (8). Since sufficient enzyme systems do not develop during pregnancy, caffeine metabolism might be extended up to 9-11 hours (9). Because of these effects, caffeine is known to adversely affect fetal development and especially kidney development (10). Therefore, several studies have been conducted on the teratogenic effects of caffeine in recent years. Antioxidants are especially targeted in the studies (11-13).

Melatonin, also known as $\mathrm{N}$-acetyl 5 methoxy tryptamine, is secreted by the pineal gland, especially at night. In addition to adjusting the basic biological rhythm, it is also involved in other basic tasks, such as cell regeneration, strengthening the immune system and regulating body temperature. Melatonin is one 
of the most powerful antioxidants known due to its lipophilic structure (14).

High-dose caffeine is known to adversely affect the kidneys and is closely associated with polycystic kidney disease, kidney stones, and hypertension (15). In addition, it has been recently shown that caffeine negatively affects fetal kidney development during the intrauterine period and causes oxidative stress (16). In line with this objective, melatonin may be targeted as a new treatment against the teratogenic effects of caffeine on the kidney.

In recent studies, total antioxidant status (TAS), total oxidant status (TOS), oxidative stress index (OSI), glutathione (GSH), glutathione disulfide (GSSG), superoxide dismutase (SOD), thiobarbituric acid reactive substances (TBARS) substances such as oxidative stress markers have been shown to be used (17). Therefore, in this study, the parameters were targeted as markers of oxidative stress.

In summary, although the teratogenic effects of caffeine on kidney development were shown in the literature, a study examining the protective effects of melatonin on these effects has not been performed yet. In this study, the teratogenic effect of caffeine on fetal kidney development and the protection of melatonin against the teratogenicity were investigated.

\section{MATERIAL and METHOD}

\section{Animals}

Wistar-Albino rats $(n=24), 5-7$ months old, weighing 180-220 g were used in our study from Erciyes University Experimental Animals and Clinical Research Center (DEKAM). For the research, ethics committee permission of Erciyes University animal experiments local ethics committee dated 11.01.2017 and numbered 17/003 was obtained. The rats were caged at $5.00 \mathrm{pm}$, with two females and one male, for their match. The following morning, female rats were subjected to a vaginal smear test at $7.00 \mathrm{am}$.
Females with sperm on the smear test were accepted as 0.5 days pregnant. The rats were kept in specially prepared, automatically air-conditioned rooms with constant temperatures of $19-21{ }^{\circ} \mathrm{C}$ and 12 hours of light/dark periods during the study. Rats were fed with normal pellet feed.

1. Control group (C): Serum physiological (SF), $(1 \mathrm{~mL} / \mathrm{kg})$ was applied i.p.

2. Sham group (S): $0.1 \mathrm{~mL}$ of hanks was administered i.p.

3. Low-dose caffeine group (LDC): $30 \mathrm{mg} / \mathrm{kg}$ caffeine was administered as gavage.

4. Low dose caffeine + Melatonin group (LDC + M): $30 \mathrm{mg} / \mathrm{kg}$ caffeine as gavage and $10 \mathrm{mg} / \mathrm{kg}$ melatonin were applied as i.p.

5. High-dose caffeine group (HDC): $60 \mathrm{mg} / \mathrm{kg}$ caffeine was administered as gavage.

6. High dose caffeine + Melatonin group (HDC $+M): 60 \mathrm{mg} / \mathrm{kg}$ caffeine as gavage and $10 \mathrm{mg} / \mathrm{kg}$ melatonin were administered as i.p.

7. Melatonin group $(\mathrm{M}): 10 \mathrm{mg} / \mathrm{kg}$ melatonin was given as i.p.

Experimental procedure was shown in (Figure 1).

\section{Preparation of Injections}

Caffeine and melatonin powder $98 \%$ were obtained from Sigma Aldrich. Drinking water was used as the solvent solution to adjust the amount of caffeine to be given to the rats. In the process of dissolving melatonin in powder form, a hanks solution was used. Both substances were prepared daily and no stock solution was made.

\section{Manipulation of Rats and Obtaining of Fetus}

Pregnant rats were anesthetized with ketamine $(75 \mathrm{mg} / \mathrm{kg})$ and xylazine $(10 \mathrm{mg} / \mathrm{kg})$ on the 20th day of gestation. The uterus and the fetuses were dissected individually with their placentas. The kidneys of the animals were collected in sterile plastic bags and stored at $-80{ }^{\circ} \mathrm{C}$ until biochemical analysis. 


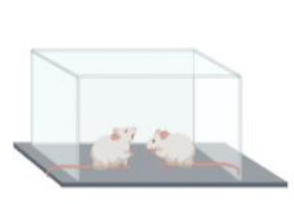

Male and

Female Rats

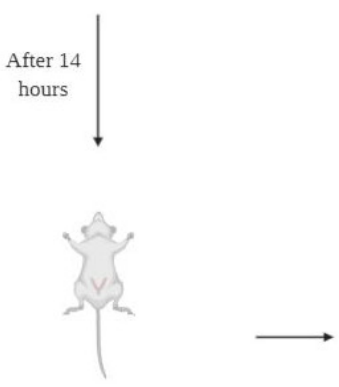

Pregnant Rats
Control group:

Serum physiologic

$(1 \mathrm{ml} / \mathrm{kg})$ i.p

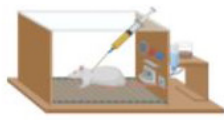

Sham group: $0.1 \mathrm{ml}$ hanks i.p

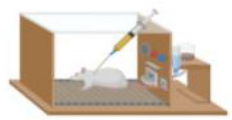

Low dose caffeine group: $30 \mathrm{mg} / \mathrm{kg}$ caffeine gavage

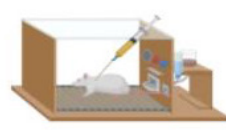

Low dose caffeine + melatonin group: 30 $\mathrm{mg} / \mathrm{kg}$ caffeine gavage and 10

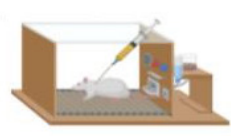
$\mathrm{mg} / \mathrm{kg}$ melatonin i.p

High dose caffeine group: $60 \mathrm{mg} / \mathrm{kg}$ caffeine gavage

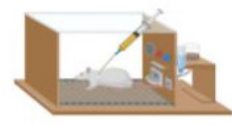

Disection of kidney tissue Biochemical Analysis

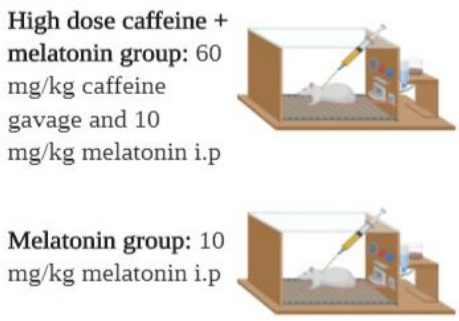

Figure 1. Summary diagram of the whole study. Biochemical analyzes of kidney tissues were performed in seven different groups

\section{Biochemical Analysis}

\section{Tissue preparation and protein determination}

The kidney tissue used for analysis was placed in microcentrifuge tubes, washed 3 times with $1 \mathrm{~mL}$ of $50 \mathrm{mM} \mathrm{PBS}$ and aspirated. The whole tissues were homogenized in cold potassium phosphate buffer (50 $\mathrm{mM}, \mathrm{pH}$ 7.4). Tissue protein levels were measured after appropriate dilutions had been made in the supernatants. The protein content of the samples was determined by the method of Lowry et al. (18) using bovine serum albumin as standard.

\section{Oxidative stress parameters}

Oxidative stress parameters (TAS, TOS and SOD levels) were determined by the spectrophotometric method. TAS and TOS tissue levels were calculated according to Erel (19). A known amount of antioxidant (1.65 mmol/l) was used to calculate the antioxidant levels in the samples. The TAS level was presented as mmol Trolox equivalent/l ( $m$ mol Trolox equivalent/l). The assay was calibrated with a standard hydrogen peroxide solution $(39.16 \mu \mathrm{mol} / \mathrm{l})$ to determine the TOS level. The results are presented as $\mu \mathrm{mol}$ $\mathrm{H}_{2} \mathrm{O}_{2}$ equivalent/I ( $\mu \mathrm{mol} \mathrm{H}_{2} \mathrm{O}_{2}$ equivalent/I). Other 
oxidative stress parameters such as GSH (Cat. No: E-BC-K030-M), GSSG (Cat. No: 703002, Cayman, USA) and SOD (Cat. E-BC-K020, Elabscience, USA) according to the manufacturer's instructions microplate reader (BioTek Instruments, EL $\times 800$ TM, USA). Commercial ELISA kits (EIA 5396 DRG, Germany) were used for vitamin $\mathrm{D}$ analysis.

\section{Determination of $\mathrm{Ca}^{+2}$}

Total $\mathrm{Ca}^{+2}$ was assessed using the calcium colorimetric assay kit (ab102505; Abcam) according to the manufacturer's data sheet. 25 standard $L$ of standard solution and 25 sup $L$ of supernatant (diluted 1: 10) extracted from the tissue were mixed with 45 $\mu \mathrm{L}$ of chromogenic reagent and $30 \mu \mathrm{L}$ of test buffer. The mixture was incubated in the dark for 15 minutes at room temperature. The signal was scanned at 575 $\mathrm{nm}$ (Thermo Varioscan). The calcium concentration in the samples was calculated according to the technique described in 2018 by Sen et al.

\section{Statistical analysis}

All analyses were performed with SPSS version 23.0 (IBM Co., NY, USA). Data were given as mean (standard deviation). Differences between the groups were analyzed by one-way analysis of variance (ANOVA) and Post hoc Tukey test for continuous variables and parametric data, respectively. Kruskal-Wallis and Post hoc Dunn tests were used for nonparametric data. $\mathrm{p}<0.05$ was considered statistically significant.

\section{RESULTS}

The highest TAS values were obtained in the control and melatonin groups, respectively. Melatonin administration significantly increased the antioxidant status in a dose-dependent manner compared to the caffeine group. Dose-dependent melatonin showed a stronger antioxidant effect as used without caffeine. TOS values showed the highest oxidant effect in HDC group. The control group had the lowest value compared to the others. Oxidative stress index was calculated by TOS/TAS ratio. OSI was significantly higher in the HDC group and lower in the melatonintreated groups (Table 1). GSH and GSH/GSSG were the highest in melatonin group and GSSG was the highest in HDC group. Melatonin decreased GSSG and increased GSH and GSH/GSSG (Table 1). SOD was the highest in HDC group. Intracellular calcium and vitamin $\mathrm{D}$ values of melatonin group were higher than all other groups. According to these results, melatonin significantly reduced oxidative stress by stimulating the antioxidant system.

\section{DISCUSSION}

Oxidative stress may disrupt various physiological processes, including cell damage and triggering apoptosis. Melatonin has antioxidant effects and might affect antioxidant enzyme activity and cellular mRNA levels under physiological or high oxidative stress conditions. The beneficial effects of melatonin on cellular toxicity induced by free radicals and peroxynititis have emerged in numerous experimental and clinical studies $(20,21)$.

It is emphasized by several researchers that cytotoxic agents negatively affect the development of organs during embryo-fetal development (22).

In 2019, it was aimed to evaluate the possible antioxidant effect of pharmacological doses of melatonin on band-3 protein anion exchange ability. The findings obtained in the study showed the antioxidant power of melatonin for in vitro oxidative stress model (23). In another study, it was purposed to determine the effects of melatonin on antioxidant capacities and arginine metabolism in lung tissue and also on tissue inflammation and oxidative damage caused by carbon tetrachloride $(\mathrm{CCl} 4)$ exposure in rats. According to results, melatonin prevented tissue inflammation and the oxidative stress observing after molecules exposure to $\mathrm{CCl} 4$ (24). It was also reported that melatonin, as an antioxidant, provides strong protection to cell organelles exposed to abundant 
Table 1. Biochemical parameters of fetus kidney tissue

\begin{tabular}{|c|c|c|c|c|c|c|c|c|}
\hline Parameters & Control & $\begin{array}{l}\text { Melatonin } \\
\text { Group }\end{array}$ & LDC Group & HDC group & $\begin{array}{c}\text { LDC+Melatonin } \\
\text { Group }\end{array}$ & $\begin{array}{l}\mathrm{HDC}+\text { Melatonin } \\
\text { Group }\end{array}$ & Sham Group & $\mathrm{p}$ \\
\hline TAS & $0.49 \pm 0.02 a$ & $0.51 \pm 0.02 a$ & $0.28 \pm 0.02 b$ & $0.14 \pm 0.00 \mathrm{c}$ & $0.35 \pm 0.03 d$ & $0.19 \pm 0.02 \mathrm{e}$ & $0.42 \pm 0.03 f$ & 0.001 \\
\hline TOS & $7.48 \pm 1.21 \mathrm{a}$ & $8.12 \pm 0.32 a b$ & $10.63 \pm 0.65 c$ & $13.68 \pm 0.64 d$ & $8.16 \pm 0.97 \mathrm{ae}$ & $8.07 \pm 1.22 \mathrm{af}$ & $9.12 \pm 0.79$ bef & 0.001 \\
\hline OSI & $1.49 \pm 0.19 a$ & $1.59 \pm 0.10 \mathrm{ab}$ & $3.73 \pm 0.40 c$ & $9.53 \pm 0.75 d$ & $2.34 \pm 0.36 \mathrm{e}$ & $4.19 \pm 0.25 c$ & $2.20 \pm 0.43 \mathrm{be}$ & 0.001 \\
\hline GSH & $2.15 \pm 0.06 a$ & $2.20 \pm 0.15 a$ & $1.16 \pm 0.12 b$ & $0.50 \pm 0.14 c$ & $1.53 \pm 0.15 d$ & $0.96 \pm 0.07 \mathrm{~b}$ & $1.78 \pm 0.18 \mathrm{e}$ & 0.001 \\
\hline GSSG & $0.47 \pm 0.07 a$ & $0.50 \pm 0.02 \mathrm{ab}$ & $0.65 \pm 0.04 c$ & $0.83 \pm 0.03 d$ & $0.50 \pm 0.06 \mathrm{ae}$ & $0.51 \pm 0.05 \mathrm{af}$ & $0.57 \pm 0.04$ bef & 0.001 \\
\hline GSH/GSSG & $215.34 \pm 6.91 a$ & $220.87 \pm 15.93 a$ & $116.60 \pm 12.83 b$ & $50.72 \pm 14.59 c$ & $153.64 \pm 15.45 d$ & $96.45 \pm 7.91 \mathrm{e}$ & $50.52 \pm 2.92 c$ & 0.001 \\
\hline TBARS & $0.84 \pm 0.13 a$ & $0.91 \pm 0.03 a b$ & $1.19 \pm 0.07 c$ & $1.51 \pm 0.07 d$ & $0.92 \pm 0.11 \mathrm{ae}$ & $0.92 \pm 0.10 \mathrm{af}$ & $1.02 \pm 0.08$ bef & 0.001 \\
\hline SOD & $9.89 \pm 1.60 a$ & $10.68 \pm 0.43 a b$ & $13.83 \pm 0.86 c$ & $17.50 \pm 0.83 \mathrm{~d}$ & $10.68 \pm 1.28 \mathrm{ae}$ & $10.75 \pm 1.04 a f$ & $11.94 \pm 0.99 \mathrm{bef}$ & 0.001 \\
\hline $\mathrm{Ca}$ & $3.79 \pm 0.18 \mathrm{a}$ & $3.89 \pm 0.18 \mathrm{a}$ & $2.41 \pm 0.14 b$ & $1.52 \pm 0.04 c$ & $2.78 \pm 0.23 d$ & $1.69 \pm 0.19 c$ & $3.30 \pm 0.24 \mathrm{e}$ & 0.001 \\
\hline vіт D & $2.13 \pm 0.09 a$ & $2.18 \pm 0.10 \mathrm{a}$ & $1.27 \pm 0.08 b$ & $0.71 \pm 0.02 c$ & $1.53 \pm 0.14 d$ & $0.88 \pm 0.10 c$ & $1.82 \pm 0.15 \mathrm{e}$ & 0.001 \\
\hline
\end{tabular}

There is no significant difference between the groups with the same letters (a, b, c, d, e, f). $p<0.05$ was considered significant. There was a significant decrease in TAS measurement in HDC group compared to control group. There was a significant increase in $\mathrm{HDC}+$ melatonin group compared to $\mathrm{HDC}$ group.

free oxygen radicals (25).

In 2019, pregnant mice were injected with energy drinks containing caffeine. As a result of this study, it was observed that perinatal exposure to energy drinks containing caffeine caused oxidative stress, tissue injury and behavioral changes in mouse newborns. Those effects have been reported to occur especially in kidney, liver and brain tissue. Therefore, it has been stated that the consumption of caffeine and energy drink during pregnancy and lactation has a negative effect in newborns and it should be seen as an essential health problem (10).

In another study conducted in 2019, the effects of melatonin on placental oxidative stress and intrauterine inflammation were aimed. It was observed that cardiovascular damage, mal- perfusion and inflammation caused by oxidative stress decreased to reasonable levels as a result of melatonin exposure (26). It was stated that targeting of the use of melatonin in pregnancy and lactation would be valuable in the prevention of various adult chronic diseases and especially cardiovascular and neurological diseases in the next period (27). However, in the literature, there is no study examining the protective effect of melatonin in spite of the intrauterine oxidative stress caused by caffeine and its teratogenicity on the kidney.

In the light of these information, in this study, we examined the teratogenic effect of caffeine on fetal kidney development and the protection of melatonin against this teratogenicity through biochemical parameters. According to our study, HDC group had 
the lowest GSH activity. GSH increased in $\mathrm{HDC}+\mathrm{M}$ group after caffeine treatment following melatonin administration.

In addition, TAS, TOS, SOD and Vitamin-D are crucial biomarkers in the assessment of oxidative damage. It was determined that melatonin increased TAS levels and decreased TOS levels in HDC group. The highest SOD value was observed in the HDC group and the lowest value was recorded in the control group.

\section{CONCLUSION}

The results showed that melatonin has a key role in reducing the teratogenic effects of caffeine and oxidative stress. Therefore, melatonin is a potential treatment for oxidative stress and caffeine teratogenicity in embryonic development.

\section{REFERENCES}

1. Prakash R, Tanuja S, Gokulnatha. Review of oxidative stress in relevance to uremia. Clin Quer: Nephrol, 2012; 1 (3): 215-21.

2. Ling, $X C$, Ko-Lin K. Oxidative stress in chronic kidney disease. Ren ReplaceTher, 2018; 4 (1): 53.

3. Sultana Z, Maiti K, Aitken J, Morris J, Dedman L, Smith R. Oxidative stress, placental ageing-related pathologies and adverse pregnancy outcomes. Am J Reprod Immunol, 2017; 77 (5): e12653.

4. Knight CA, Knight I, Mitchell DC, Zepp JE. Beverage caffeine intake in US consumers and subpopulations of interest: estimates from the Share of Intake Panel survey. Food Chem Toxicol, 2004; 42 (12): 1923-30.
5. Xu F, Liu P, Pekar JJ, Lu H. Does acute caffeine ingestion alter brain metabolism in young adults? Neuroimage, 2015; 110: 39-47.

6. Ng YP, Or TCT, Ip NY. Plant alkaloids as drug leads for Alzheimer's disease. Neurochem Int, 2015; 89: 260-70.

7. Fox GP, Wu A, Yiran L, Force L. Variation in caffeine concentration in single coffee beans. J Agr Food Chem, 2013; 61 (45): 10772-8.

8. Nehlig A, Jean-Luc D, Gérard D. Caffeine and the central nervous system: mechanisms of action, biochemical, metabolic and psychostimulant effects. Brain Res Rev, 1992; 17 (2): 139-70. 
9. Grosso LM, Michael BB. Caffeine metabolism, genetics, and perinatal outcomes: a review of exposure assessment considerations during pregnancy. Ann Epidemiol, 2005; 15 (6): 460-6.

10. Al-Basher GI, Aljabal H, Almeer RS, Allam AA, Mahmoud AM. Perinatal exposure to energy drink induces oxidative damage in the liver, kidney and brain, and behavioral alterations in mice offspring. Biomed Pharmacother, 2018; 102: 798-811.

11. Matijasevich A, Barros FC, Santos IS, Yemini A. Maternal caffeine consumption and fetal death: a case-control study in Uruguay. Paediatr Perinat Epidemiol, 2006; 20 (2): 100-9.

12. Li J, Zhao H, Song JM, Zhang J, Tang YL, Xin CM. A meta-analysis of risk of pregnancy loss and caffeine and coffee consumption during pregnancy. Int J Gynecol Obstet, 2015; 130 (2): 116-22.

13. Weng X, Roxana O, De-Kun L. Maternal caffeine consumption during pregnancy and the risk of miscarriage: a prospective cohort study. Am J Obstet Gynecol, 2008; 198 (3): 279-e1-8.

14. Dollins $A B$, Zhdanova IV, Wurtman RJ, Lynch HJ, Deng $M H$. Effect of inducing nocturnal serum melatonin concentrations in daytime on sleep, mood, body temperature, and performance. Proc Natl Acad Sci, 1994; 91 (5): 1824-8.

15. Meca R, Balbo BE, Ormanji MS, Fonseca JM, lannuzzi LR, Santana CE, et al. Caffeine accelerates cystic kidney disease in a Pkd1-deficient mouse model. Cell Physiol Biochem, 2019; 52: 1061-74.

16. Nisari M, Yılmaz S, Göçmen AY, Karataș E, Özge A. The protective effect of caffeine and melatonin on antioxidant enzymes in rat fetal lung tissues. J Surg Med, 2019; 3 (11): 805-8.

17. Czerska $M$, Mikolajewska $\mathrm{K}$, Zielinski $M$, Gromadzinska J, Wasowicz W. Today's oxidative stress markers, Medycyna Pracy, 2015; 66(3):393405.
18. Lowry $\mathrm{OH}$, Rosebrough NJ, Farr AL, Randall RJ. Protein measurement with the folin phenol reagent. J BiolChem, 1951; 193: 265-75.

19. Erel OA. Novel automated direct measurement method for total antioxidant capacity using a new generation, more stable ABTS radical cation. Clin Biochem, 2004; 37 (4): 277-85.

20. Galano A, Dun XT, Russel JR. Melatonin as a natural ally against oxidative stress: a physicochemical examination. J Pineal Res, 2011; 51 (1): 1-16.

21. Tan DX, Manchester LC, Hardeland R, Lopez-Burillo S, Mayo JC, Sainz RM, et al. Melatonin: a hormone, a tissue factor, an autocoid, a paracoid, and an antioxidant vitamin. J Pineal Res, 2003; 34 (1): 75 8.

22. Groenman F, Sharon U, Martin P. The molecular basis for abnormal human lung development. Neonatology, 2005; 87 (3): 164-77.

23. Morabito R, Alessia R, Angela M. Melatonin Protects Band 3 Protein in Human Erythrocytes against H2O2-Induced Oxidative Stress. Molecules, 2019; 24 (15): 2741.

24. Radovic M, Ristic L, Krtinic D, Rancic M, Nickovic V, Vujnovic ZZ, et al. Melatonin treatment prevents carbon tetrachloride-induced acute lung injury in rats by mitigating tissue antioxidant capacity and inflammatory response. Bratisl Med J, 2019120 (7): 527-31.

25. Reiter RJ, Rosales CS, Tan DX, Jou MJ, Galano $\mathrm{A}, \mathrm{Xu}$ B. Melatonin as a mitochondria-targeted antioxidant: one of evolution's best ideas. Cell Mol Life Sci, 2017; 74 (21): 3863-81.

26. Lee JY, Li S, Shin NE, Na Q, Dong, J, Jia B, et al. Melatonin for prevention of placental malperfusion and fetal compromise associated with intrauterine inflammation-induced oxidative stress in a mouse model. J Pineal Res, 2019; e12591.

27. Hsu CN, Huang LT, Tain YL. Perinatal use of melatonin for offspring health: focus on cardiovascular and neurological diseases. Int J Mol Sci, 2019; 20 (22): 5681. 